\title{
Analysis of the Internationalization and Value Chain Activities in Chilean Enterprises
}

Ana María Vallina-Hernández ${ }^{1}$, Hanns de la Fuente-Mella², and Rodrigo Fuentes-Solís ${ }^{3}$

ABSTRACT

\begin{abstract}
An open economy inserted in an environment with increasing participation of global value chains, such as the Chilean economy, requires information about how its business integrates into international markets. The contribution of this study is that it evaluates the stages and patterns of Chilean firms' internationalization by using a value chain activities framework, identifying four categories. The intensity of upstream and downstream business activities allows classifying the mode in each of the four categories. Members of the Sociedad de Fomento Fabril (SOFOFA) answered the survey design for this study. Results illustrate companies' behavior concerning international trade and foresight of further critical issues.
\end{abstract}

KEY WORDS: International Trade, Innovation, Latin American, Internationalization Strategy, Value Chain Activities.

JEL Classification: F23, F14, M16, D22.

'Escuela de Negocios y Economía, Facultad de Ciencias Económicas y Administrativas, Pontificia Universidad Católica de Valparaíso, Valparaíso 2340031, Chile.

2Escuela de Comercio, Facultad de Ciencias Económicas y Administrativas, Pontificia Universidad Católica de Valparaíso, Valparaíso 2340031, Chile.

${ }^{3}$ Escuela de Ingeniería Comercial, Facultad de Economía y Negocios, Universidad de Talca, Avda. Lircay s/n Talca, 3460000, Chile.

\section{Introduction}

The Chilean economy is embedded in the modern globalization movement. Foreign goods and services are widely available in Chile and affect trade and capital flows. In Chilean stores, merchandise produced worldwide is displayed in the stands together. Consumers who cannot find what they like can go on the Internet, with its wide-reaching stores where thousands upon thousands of producers and consumers gather to trade various products and buy what they want. International trade has extended to services thanks to technologies such as the Internet and smartphones. The internationalization of other factors of production such as labor and capital has also increased considerably,

Correspondence concerning this article should be addressed to: Rodrigo Fuentes-Solís, Escuela de Ingeniería Comercial, Facultad de Economía y Negocios, Universidad de Talca, Avda. Lircay s/n Talca, 3460000, Chile. E-mail: rodrigo.fuentes@utalca.cl affecting most countries worldwide. Today highly skilled labor such as managers and professionals live and work in countries apart from where they were born. Capital moves across world regions freely and swiftly, with few boundaries.

Today more than ever, firms need to orchestrate their value chain activities internationally to become and remain globally competitive, regardless of COVID-19. Unfortunately, it is still unclear for most business leaders, especially in emerging economies and less developed countries, how their companies should become internationally engaged and how to do it successfully. Specifically, business leaders need to know the best international business development practices and the factors that facilitate or impede such endeavors. This study contributes to closing such a gap by evaluating the scope and patterns in Chilean firms' internationalization. Since the 1970s, Chile has applied open 
trade policies and currently has implemented more free trade agreements than any other country; with most Latin American countries, the United States, Canada, the European Union, Korea (the first such trade agreement between an Eastern and a Western country), China, Japan, Australia, and Vietnam, among others. Therefore, it is necessary to develop systematic knowledge for business leaders in Chile to recognize the best practices to internationalize their business operations, allowing them to successfully compete against other firms within the expanded markets created by Chilean free trade agreements.

The internationalizing endeavors of Chilean enterprises considered in the study were analyzed following Curci et al. (2013). This framework classifies firms' upstream and downstream value chain activities as domestic or international across time, providing an understanding of the stages through which firms internationalize (or not), thereby obtaining an array of internalization patterns. Firms may internationalize by selling to (exporting) or buying from (importing) world markets. Exports usually get much more attention than imports. This study applies a survey to managers of companies belonging to the Sociedad de Fomento Fabril (SOFOFA). The survey results allow understanding the extent of internationalization, challenges, and opportunities firms encounter as they move from being domestically focused to internationally engaged. The findings suggest the characteristics of Chilean firms and the perceptions of their managers vary across framework classification categories (Paz et al., 2016). In addition, Chilean firms' internationalization experiences are dynamic; firms engage and disengage from international markets across time.

This paper is organized as follows: the literature review section illustrates how our study fits with the current state of knowledge in firm Internationalization within the Latin American context. Then, the following section discusses the methodology used to classify Chilean firms according to the intensity of upstream and downstream value chain activities firms undertake internationally. Afterward, the divisions present the research methodology, empirical results, and the summary and concluding remarks.

\section{Theoretical Framework}

The contemporary globalization movement makes it essential for business leaders to understand the factors that facilitate and impede company internationalization efforts. However, such knowledge is relatively limited currently. The literature is ample when it comes to an understanding of internationalization drivers and performance in large multinational businesses from developed economies. However, our knowledge is particularly limited in understanding the motivations of large or small and medium-sized corporations (SMEs) from emerging markets (Dunning, 2008). The limited availability of secondary data for business in general and SMEs makes it difficult for researchers to study these kinds of companies; this holds for companies and SMEs in developed and emerging markets (Buckley \& Cason, 2016). Therefore, a deeper understanding of how firms from emerging markets such as Chile become internationally integrated over time is still needed.

Aulakh (2007) studies emerging multinationals from developing economies and provides insights regarding motivations, paths, and performance. Multinational companies from developing countries are said to invest in other developing countries because they know how to deal with institutional voids and are becoming active players in developed economies. In addition, these companies are becoming global players and are not just part of supply chains from another MNE from developed economies. Lou and Tung (2007) also study the international expansion of emerging market enterprises and provide a springboard perspective. The authors argue emerging market MNEs use their business relationship with global partners as a springboard for their internationalization.

The extent of knowledge regarding Latin American firms' internationalization is also somehow limited but growing. Perez-Batres et al. (2010) review the Latin American contribution to IB scholarship and argue Latin American IB scholars are underrepresented in the literature and the editorial boards of IB journals. They state that studies about Latin America as a region are scarce. Moreover, the articles that study the area are usually from North America; Latin American scholars have only a marginal representation $(0,58 \%)$ and usually participate as co-authors with non-Latin 
American scholars. Carneiro and Brenes (2014) argue that only a minimal percentage of peer review management publications focus on Latin American issues or are produced by Latin American authors. It appears most such publications focus either on Latin American multinationals and their foreign direct investment patterns, or in high-tech born-global Latin American firms, or a particular characteristic of the firms' internationalization processes (Christensen et al., 1987; Dominguez \& Sequeira, 1993; Brenes, 2000; Ickis, 2000; Thomas \& Grosse, 2005; Anand et al., 2006). A few multi-country studies suggest the conditions across Latin American countries are so varied that it is difficult to compare and contrast internationalization experiences of firms across the region. Our current state of knowledge on the internationalization processes of Latin American firms is illustrated in the following paragraphs (Moori et al., 2007).

Multilatinas or multinational companies originally from Latin American began growing in the early 1990 s as a response to the opening and globalization of product and financial markets throughout the region and the world. Various authors have studied Multilatinas (Cuervo-Cazurra, 2007; CuervoCazurra, 2008; Santino, 2008; Fleury \& Fleury, 2011; and Carneiro \& Brenes, 2014). These authors find Multilatinas prefer horizontal Foreign Direct Investments (FDI) to immerse themselves in global value chains. In addition, the internationalization processes of Multilatinas were driven by economic reforms and the globalization of financial markets; the competitive characteristics of industries affect Multilatinas' subsidiary type and entry mode. As expected, according to the revised Uppsala Model (Johanson \& Vahlne, 2009), Multilatinas follow incremental internationalization processes and typically engage in export activity before undertaking more advanced entry modes such as FDI; product offerings are related to cultural distances between home and host markets, and the "south-south" FDI trend is reshaping the center-periphery geography. The augmented Upsala model (Johanson \& Vahlne, 2017) is a dynamic model that considers change and state variables. It continues to analyze business internalization, including intermittent decision processes and continuous knowledge development processes, inserted in a changing environment with uncertainty and imperfect information. The model includes reconfiguring and coordinating resource allocation. The state variables are capability variables, which are dynamic, and commitment/performance variables. Consequently, time has become a crucial variable to explain business behavior in the international markets.

Global strategy analysis focuses on FDI while the global value chain emphasis on cross-border production network. Consequently, an integrative and interdisciplinary approach is required to understand the behavior and decision-making of firms that adopt different strategies to overcome the international market (Pananond et al., 2020). In that sense, the Value Chain Internationalization framework complements the former model (Curci et al., 2013). Furthermore, according to Morkovina et al. (2016), transnational enterprises expand world development. Understanding proper behavior in an interdisciplinary setting to face disruptive events and improve public trade and investment policies is thus essential to enhanced employment.

Lederman etal. (2014) study the Internationalization of Latin American SMEs and find companies with a shallow level of engagement in export activities. Among those engaged, only a few tend to remain engaged for over a year. Moreover, export promotion policies may not have yet had the expected impact in Latin America. Schulz et al. (2009) study the internationalization processes of SMEs in other world regions and suggest that SMEs' internationalization is not explained by classical internationalization theories; specifically, they are not path-dependent, not emergent, and not incremental.

Bianchi (2014) studies Chilean firms and finds success in internationalization depends on specific firm capabilities and resources such as belonging to a business conglomerate, developing critical partnerships, belonging to networks, being innovative, and having a market orientation, among other similar characteristics. Moori et al. (2007) compare successful and unsuccessful exporters from Argentina, Chile, and Colombia and find success determinants vary across countries. For instance, technology and the evolutionary path determine the success of Argentinean firms; trade volume 
influences Colombian corporations' success, and factors such as technological content level and firm size explain business success for Chilean enterprises. According to Finchestein (2013), Chilean business internationalization through foreign direct investment starts in the 1990s, investing in neighboring countries, belonging principally to the service sector; this internationalization process coincides with the application of the Chilean trade policy-oriented to deepen integration through negotiating free trade agreements. Nevertheless, other secondary factors such as the institutional environment for financing are also important (De la Fuente-Mella et al., 2020a; 2020b).

Geldres et al. (2011) study SMEs and find that these companies tend to export to closer markets in terms of psychological distance; however, they also find SMEs that export to more psychologically distant markets tend to showcase better export performance or returns. Poblete and Amorós (2013) support such findings and suggest variables that explain Chilean SME internationalization success includes psychological distance and previous experience in international markets. In general, prior studies on Chilean companies' internationalization processes cover multiple periods and use quantitative and qualitative methodological approaches. Nevertheless, our understanding of internationalization processes in Chilean firms is limited. This study contributes to the literature by using the value chain internalization framework to comprehensively evaluate the multiple factors that may explain firm success or failure along the internationalization journey.

Studies may apply the value chain internationalization framework to all companies regardless of their size. Its classification identifies the stage of corporate internationalization in a framework category. Specifically, firms are classified into four categories depending upon the intensity of domestic and international value chain activities (please see Figure 1). Domestically focused firms (Category 1) engage exclusively in domestic upstream and downstream activities. Upstream integrated firms (Category 2) also engage in upstream activities

\section{Figure 1}

Value Chain Internationalization Framework

\begin{tabular}{|c|c|c|}
\hline $\begin{array}{l}\text { Intensity of } \\
\text { Downstream } \\
\text { Activities }\end{array}$ & $\begin{array}{l}\text { Domestic } \\
\text { (Home Market) }\end{array}$ & $\begin{array}{l}\text { International } \\
\text { (Host Markets) }\end{array}$ \\
\hline $\begin{array}{l}\text { Domestic } \\
\text { (Home Market) }\end{array}$ & $\begin{array}{l}1 \\
\text { Domestically } \\
\text { Focused }\end{array}$ & $\begin{array}{l}3 \\
\text { Downstream- } \\
\text { Integrated } \\
\text { (Market-Seeking) } \\
\text { (Strategic Asset- } \\
\text { Seeking) }\end{array}$ \\
\hline $\begin{array}{l}\text { International } \\
\text { (Host Markets) }\end{array}$ & $\begin{array}{l}2 \\
\text { Upstream- } \\
\text { Integrated } \\
\text { (Resource-Seeking) } \\
\text { (Efficiency-Seeking) } \\
\text { (Strategic Asset- } \\
\text { Seeking) }\end{array}$ & $\begin{array}{l}4 \\
\text { Internationally } \\
\text { Engaged } \\
\text { (Market-Seeking) } \\
\text { (Resource-Seeking) } \\
\text { (Efficiency-Seeking) } \\
\text { (Strategic Asset- } \\
\text { Seeking) }\end{array}$ \\
\hline
\end{tabular}

Source: Curci et al. (2012), The Internationalization of Business in the Greater Indianapolis Area: Understanding Their Scope and Strategies. 
internationally; however, these firms only perform downstream activities domestically. Downstream integrated firms (Category 3) also engage in downstream activities internationally; however, these firms only perform upstream activities domestically. Finally, internationally engaged firms (Category 4) also engage simultaneously in upstream and downstream activities internationally.

This framework allows us to identify the chronological dynamics of corporate internationalization patterns. For instance, firms may move from being domestically focused (Category 1 firms) towards being internationally engaged (Category 4 firms). Indeed, nine potential internationalization patterns are possible as firms move from being domestically focused to internationally engaged (e.g., a firm may start in Category 1 , then move to Category 2, and then to Category 4). Nevertheless, firms may also move inwards. For instance, a firm may move from upstream or downstream integrated (Category 2 or 3 firms) towards domestically focused (Category 1 firms). Such a movement may be explained, for instance, by changes in international market conditions that make global markets less attractive (e.g., exchange rate movements that improve domestic market returns).

The framework also allows us to understand the intensity of value chain activities developed domestically or dispersed across foreign markets. Equally importantly, it also helps us identify the factors that may explain business success or failure. In addition, the internationalization practices of companies across factors such as the industrial sector or firm size may be compared within and across classification categories. We expected that firm characteristics and managers' attitudes would also vary across types. Firms also face different opportunities and challenges across categories. Therefore, empirically testing the value chain internationalization framework with SMEs, multinational companies, and born-global firms across multiple world regions would be valuable (Curci et al., 2013).

The questions of the survey to identify managers' perceptions were defined according to categories described as relevant in previous studies, such as corporate governance and its engagement in different activities, such as the topics developed in Westhead et al. (2001), Zahra (2003), and Zuchella et al. (2007).

\section{Methodology}

\subsection{Data Collected}

Data were collected from Chilean corporate managers. The sample frame for this project was a membership listing of the Sociedad de Fomento Fabril (SOFOFA), a federation of Chilean industries that brings together 38 sectorial associations and 8 regional industrial associations. A survey built using the QuestionPro software was distributed to 2,500 SOFOFA members via email. Managers were invited to participate in the study and respond to questions from either the entire organization or a specific strategic business unit (SBU), depending on which one managers were more familiar with. The survey was available for managers to participate starting in May, 2014 and it was closed for participation in July, 2014. A total of 86 firms provided valuable answers to the survey. Methodologically this research replicates the research done by Curci et al. (2012) that applied the Value Chain Internationalization Framework to the Greater Indiana Area, using the same questionnaire employed in the original study, which was translated to Spanish and adapted to the reality of Chile according to the formalities used in that country.

The development of the original survey included three distinct stages: (a) question generation, (b) question refinement using expert feedback, and (c) pretesting. For this study, the questionnaire was translated into Spanish and then pretested to identify necessary adjustments. Subsequently, some survey questions were rewritten to increase survey question clarity. In addition, the average time required for survey completion was tested to ensure managers' disposition to dedicate enough time to complete the survey. Finally, a revised version of the survey was distributed among SOFOFA members with a letter of invitation to participate. Eighty-six firms completed the survey.

A descriptive statistical analysis and ANOVA model are applied to the data to contrast behavior in the different categories defined by the framework. Afterward, a decision tree model is run to detect the most relevant variables that may explain why a firm decides to remain domestically focused, upstream-integrated, downstream-integrated, or internationally engaged, applying Python software, with the accuracy-score of Metrics library of sklearn. 


\section{Results And Discussion}

Firms were classified into the Value Chain Internationalization Framework by their responses to questions such as whether or not they sell products or services internationally and whether or not they source input factors internationally. As Figure 2 showcases, firms were distributed almost evenly across three framework categories; however, only three firms were classified into the downstream integrated category.

Our classification of Chilean firms into the value chain internationalization framework indicates 35\% of respondents are domestically focused (Category 1). This finding implies about $1 / 3$ of respondents are not active in international business activities, as they only sell goods or services within Chile and only source input factors within Chile. Similarly, $35 \%$ of respondents are classified as upstream integrated (Category 2). These firms engage in sourcing input factors internationally; however, they sell in Chile exclusively. Only $3 \%$ of respondents are classified as downstream integrated (Category 3 ). These
Chilean firms sell some of their products or services internationally while exclusively sourcing all input factors in domestic markets. Last but not least, 27\% of respondents are classified as internationally engaged. These Chilean firms are deemed to be more active in international business activities; they engage simultaneously in international selling and sourcing.

Our survey instrument also included a series of questions to determine respondents' level of international orientation or mindset. These responses allow us to classify firms into the framework based upon their international mindset rather than the actual level of international business activities. Such findings suggest that Chilean managers are more internationally minded than actual practice indicates. For instance, $56 \%$ of respondents (48 firms) are classified in Category 4 (Internationally engaged) based upon international mindset; in contrast, only $27 \%$ of respondents ( 23 firms) are classified in this category based on actual international business activities or practice.

\section{Figure 2}

Value Chain Internationalization Framework-Classification of Chilean Firms

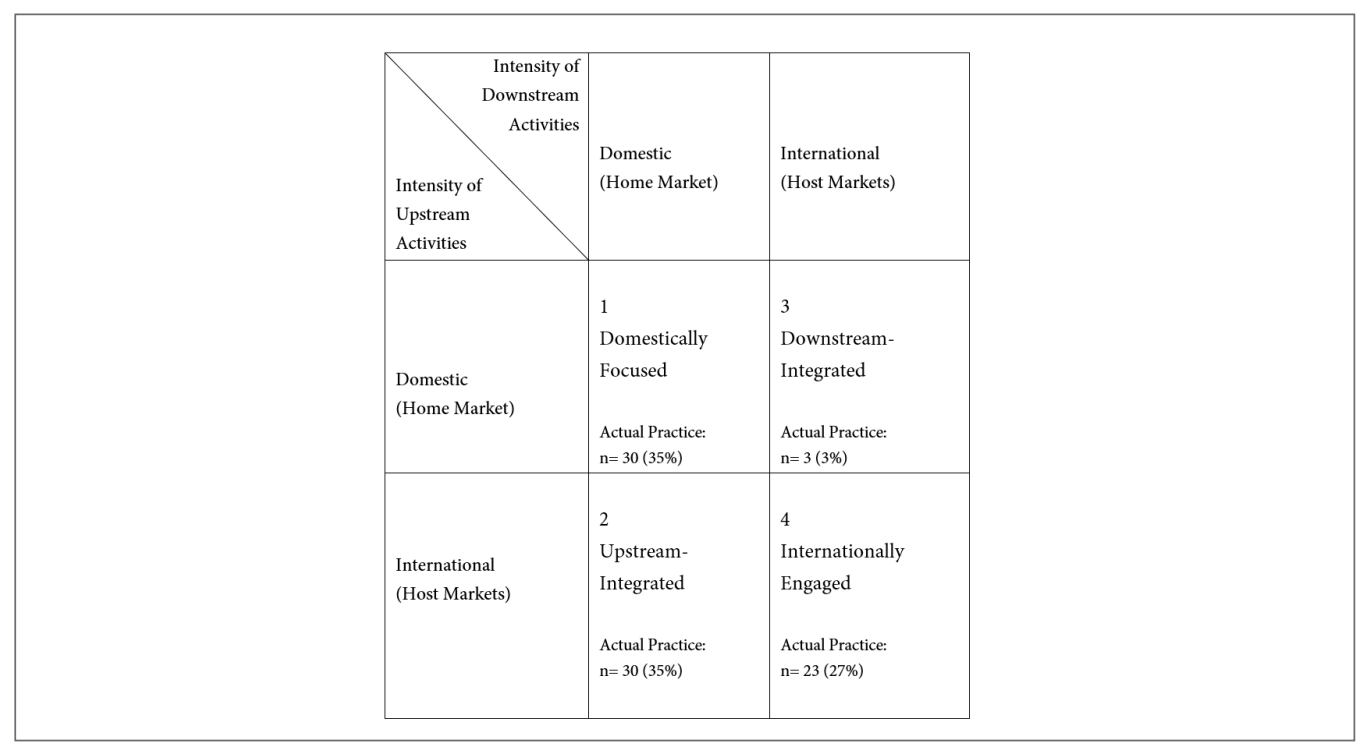




\subsection{Firm Size, Age, and Industry Representation} This section compares and contrasts business characteristics across value chain internationalization framework categories in terms of size, age, and industry representation. Table 1 illustrates firm size across categories based on annual revenue levels (only including businesses that responded to firm size survey questions). The Chilean Internal Revenue Service (IRS) defines the following types of companies based on annual income brackets: micro enterprises are firms with annual revenues below US\$100,000; small companies are firms with annual revenues between US $\$ 100,000$ to US\$1,000,000; medium-size firms are firms with annual revenues between US $\$ 1,000,000$ to US $\$ 4,200,000$; and large companies are firms with annual revenues above US\$ 4,200,000.

As Table 1 illustrates, most firms are classified as large corporations (40.3\%). Micro enterprises and small companies are equally represented (22.2\%) while medium size firms have the lowest representation (15.3\%). Firm distribution across these revenue categories seems consistent with the overall population of firms constituting the SOFOFA; while this society represents firms of all sizes a relative higher proportion of firms are deemed to be large.

The highest percentage of firms classified as internationally engaged (66.7\%) are large firms while micro-enterprises account for the lowest percentage of firms in such a category (4.8\%). These results coincide with the findings in Suhatrini et al. (2020), regarding that logistic efficiency and reliability has a positive effect in financial performance and that those qualities increase as corporate size rises. Interestingly, there are no large firms classified as downstream integrated; the three firms classified in this category are one micro, one small, and one medium-sized company. An equal percentage of micro-enterprises and large firms are classified as upstream integrated (29.6\%); firms of such sizes appear equally active in sourcing input factors internationally. The highest percentage of firms classified as domestically focused (33.3\%) are large companies. In comparison, micro-enterprises account for the second-highest percentage (28.6\%) and small and medium-sized enterprises for the lowest (19\%).

Table 1

Firm Size Across Framework Classification Categories

\begin{tabular}{|c|c|c|c|c|c|}
\hline \multicolumn{6}{|c|}{ Value Chain Internationalization Framework Category } \\
\hline Revenue & $\begin{array}{c}\text { Domestically } \\
\text { Focused }\end{array}$ & $\begin{array}{l}\text { Upstream Inte- } \\
\text { grated }\end{array}$ & $\begin{array}{c}\text { Downstream } \\
\text { Integrated }\end{array}$ & $\begin{array}{l}\text { Internation- } \\
\text { ally Engaged }\end{array}$ & Total \\
\hline Micro & $28.6 \%$ & $29.6 \%$ & $33.3 \%$ & $4.8 \%$ & $22.2 \%$ \\
\hline$<\mathrm{US} \$ 100,000$ & $(n=6)$ & $(\mathrm{n}=8)$ & $(\mathrm{n}=1)$ & $(n=1)$ & $(n=16)$ \\
\hline Small & $19.0 \%$ & $25.9 \%$ & $33.3 \%$ & $19.0 \%$ & $22.2 \%$ \\
\hline$>$ US\$100,000 & $(\mathrm{n}=4)$ & $(n=7)$ & $(\mathrm{n}=1)$ & $(\mathrm{n}=4)$ & $(n=16)$ \\
\hline \multicolumn{6}{|l|}{$<\mathrm{US} \$ 1,000,000$} \\
\hline Medium & $19.0 \%$ & $14.8 \%$ & $33.3 \%$ & $9.5 \%$ & $15.3 \%$ \\
\hline$>$ US $\$ 1,000,000$ & $(\mathrm{n}=4)$ & $(\mathrm{n}=4)$ & $(\mathrm{n}=1)$ & $(n=2)$ & $(n=11)$ \\
\hline \multicolumn{6}{|l|}{$<\mathrm{US} \$ 4,200,000$} \\
\hline Large & $33.3 \%$ & $29.6 \%$ & $0.0 \%$ & $66.7 \%$ & $40.3 \%$ \\
\hline$>\mathrm{US} \$ 4,200,000$ & $(n=7)$ & $(\mathrm{n}=8)$ & $(\mathrm{n}=0)$ & $(\mathrm{n}=14)$ & $(n=29)$ \\
\hline \multirow[t]{3}{*}{ Total } & $100 \%$ & $100 \%$ & $100 \%$ & $100 \%$ & $100 \%$ \\
\hline & $(n=21)$ & $(n=27)$ & $(\mathrm{n}=3)$ & $(\mathrm{n}=21)$ & $(\mathrm{n}=72)$ \\
\hline & Out of 30 & Out of 30 & Out of 3 & Out of 23 & Out of 86 \\
\hline
\end{tabular}


In essence, a large percentage of Chilean businesses are domestically focused and represent firms of all sizes. As expected, Chilean firms may find it easier to engage in international upstream value chain activities (30 firms) than international downstream value chain activities ( 3 firms). It is generally easier to source input factors than it is to sell products or services. In addition, firm size appears to be a key internationalization driver, as most internationally engaged Chilean firms are large businesses. Micro, small, and medium-sized firms in Chile may face higher challenges in embracing international business activities. For instance, to successfully enter foreign markets, smaller firms typically encounter challenges such as building economies of scale or securing sufficient financial resources.

Figure 3 illustrates firm age across value chain internationalization framework categories based on the number of years since the corporation was established (only including businesses that responded to company age survey questions). The corporate age range is quite dispersed, ranging from less than one year to over 164 years. The average firm age is 27 years old, and the median is 17 years old, meaning the sample is skewed towards lower firm ages. Furthermore, the mode is one year or less, equivalent to $11 \%$ of the sample. The sample contains many young firms; however, they are not concentrated in a particular framework category.

The average age for domestically focused firms is 21 years old, while the figure for upstream integrated firms is about 19 years old. The lowest average age is associated with firms classified as downstream integrated (16 years). The highest average age is shown by businesses classified as internationally engaged (43 years). Therefore, corporate age also appears to be a key internationalization driver, since internationally engaged Chilean businesses showcase the highest average years of age. This finding is consistent with the traditional view of internationalization which suggests firms increase their international engagements across time as they accumulate knowledge and experience (The Upsala Model; Johansson \& Vahlne, 2009). Nevertheless, the born-global firm literature challenges the traditional view of internationalization, arguing that due to technological infrastructure such as the Internet businesses are becoming internationally engaged in their early years of operation (Knight \& Cavusgil, 1996).

\section{Figure 3}

Firm Age Across Framework Classification Categories

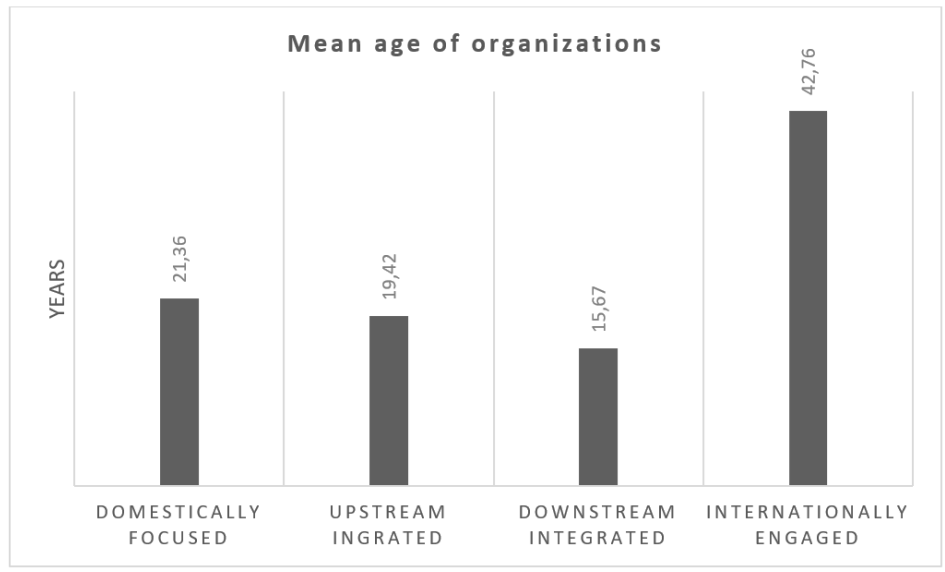


The SOFOFA member firms included in our final sample represented multiple industries. Survey respondents are classified into industry clusters using the "North American Industry Classification System" or NAICS Codes; an international industry classification system allows this study to be compared and contrasted against similar studies in other world regions. Table 2 lists the 18 industries represented in the sample. The Professional, Scientific, and Technical Services industry has the highest representation at about $20 \%$. The industries with the next highest representation levels include Other Services (14\%), Transportation and Warehousing (10.5\%), and Manufacturing (9.3\%). Thus, those four industries represent more than fifty percent of our sample. Other critical industries include Wholesale Trade, Retail Trade, Mining, Quarrying, and Oil and Gas Extraction. Notably, Professional, Scientific, and Technical Services is the only industry cluster representing each of the four framework categories. The Manufacturing industry also has the highest number of firms classified as internationally engaged. In contrast, the most significant representation of firms from multiple industries appears in the domestically focused category.

\subsection{Managers' Attitudes Towards Internationalization}

This section compares and contrasts managers' attitudes regarding some internationalization drivers and firm performance across framework categories. First, we expect managers' attitudes towards internationalization to be better in higher framework category levels; managers' international mindset should develop as firms move from a domestic focus to international engagement. Second, we expect managers to possess higher capabilities to engage in international business activities at higher framework category levels. Third, we expect managers' perception of firm performance to increase at higher framework category levels; managers should perceive a positive relationship between internationalization level and firm performance. The survey asked managers to

Table 2

Industry Representation

\begin{tabular}{|c|c|c|c|c|c|}
\hline Industry & $\begin{array}{c}\text { Domestically } \\
\text { Focused }\end{array}$ & $\begin{array}{c}\text { Upstream } \\
\text { Integrated }\end{array}$ & $\begin{array}{l}\text { Downstream } \\
\text { Integrated }\end{array}$ & $\begin{array}{l}\text { Internationally } \\
\text { Engaged }\end{array}$ & Total \\
\hline $\begin{array}{l}\text { Professional, Scientific, and Technical } \\
\text { Services }\end{array}$ & $\begin{array}{c}n=6 \\
(20 \%)\end{array}$ & $\begin{array}{c}n=5 \\
(16,7 \%)\end{array}$ & $\begin{array}{c}n=2 \\
(66,7 \%)\end{array}$ & $\begin{array}{c}\mathrm{n}=4 \\
(17,4 \%)\end{array}$ & $\begin{array}{l}\mathrm{n}=17 \\
19,8 \%\end{array}$ \\
\hline Other Services & $\begin{array}{c}n=5 \\
(16,7 \%)\end{array}$ & $\begin{array}{c}n=3 \\
(10 \%)\end{array}$ & $\begin{array}{l}\mathrm{n}=0 \\
(0 \%)\end{array}$ & $\begin{array}{c}n=4 \\
(17,3 \%)\end{array}$ & $\begin{array}{l}\mathrm{n}=12 \\
14,0 \%\end{array}$ \\
\hline Transportation and Warehousing & $\begin{array}{c}n=3 \\
(10 \%)\end{array}$ & $\begin{array}{c}\mathrm{n}=2 \\
(6,7 \%)\end{array}$ & $\begin{array}{l}\mathrm{n}=0 \\
(0 \%)\end{array}$ & $\begin{array}{c}n=4 \\
(17,4 \%)\end{array}$ & $\begin{array}{l}\mathrm{n}=9 \\
10,5 \%\end{array}$ \\
\hline Manufacturing & $\begin{array}{l}\mathrm{n}=0 \\
(0 \%)\end{array}$ & $\begin{array}{c}n=3 \\
(10 \%)\end{array}$ & $\begin{array}{l}\mathrm{n}=0 \\
(0 \%)\end{array}$ & $\begin{array}{c}n=5 \\
(21,7 \%)\end{array}$ & $\begin{array}{l}\mathrm{n}=8 \\
9,3 \%\end{array}$ \\
\hline Wholesale Trade & $\begin{array}{c}\mathrm{n}=3 \\
(10 \%)\end{array}$ & $\begin{array}{c}\mathrm{n}=1 \\
(3,3 \%)\end{array}$ & $\begin{array}{l}n=0 \\
(0 \%)\end{array}$ & $\begin{array}{c}n=1 \\
(4,3 \%)\end{array}$ & $\begin{array}{l}\mathrm{n}=5 \\
5,8 \%\end{array}$ \\
\hline Retail Trade & $\begin{array}{c}n=1 \\
(3,3 \%)\end{array}$ & $\begin{array}{c}\mathrm{n}=4 \\
(13,3)\end{array}$ & $\begin{array}{l}\mathrm{n}=0 \\
(0 \%)\end{array}$ & $\begin{array}{l}\mathrm{n}=0 \\
(0 \%)\end{array}$ & $\begin{array}{l}\mathrm{n}=5 \\
5,8 \%\end{array}$ \\
\hline $\begin{array}{l}\text { Mining, Quarrying, and Oil and Gas Ex- } \\
\text { traction }\end{array}$ & $\begin{array}{c}\mathrm{n}=1 \\
(3,3 \%)\end{array}$ & $\begin{array}{l}\mathrm{n}=0 \\
(0 \%)\end{array}$ & $\begin{array}{c}n=1 \\
(33,3 \%))\end{array}$ & $\begin{array}{c}\mathrm{n}=2 \\
(8,7 \%))\end{array}$ & $\begin{array}{l}\mathrm{n}=4 \\
4,7 \%\end{array}$ \\
\hline Construction & $\begin{array}{c}n=3 \\
(10 \%)\end{array}$ & $\begin{array}{c}\mathrm{n}=1 \\
(3,3 \%)\end{array}$ & $\begin{array}{l}\mathrm{n}=0 \\
(0 \%)\end{array}$ & $\begin{array}{l}\mathrm{n}=0 \\
(0 \%)\end{array}$ & $\begin{array}{l}\mathrm{n}=4 \\
4,7 \%\end{array}$ \\
\hline
\end{tabular}


Table 2

Filndustry Representation (Continued)

\begin{tabular}{|c|c|c|c|c|c|}
\hline Industry & $\begin{array}{l}\text { Domestically } \\
\text { Focused }\end{array}$ & $\begin{array}{l}\text { Upstream } \\
\text { Integrated }\end{array}$ & $\begin{array}{l}\text { Downstream } \\
\text { Integrated }\end{array}$ & $\begin{array}{l}\text { Internationally } \\
\text { Engaged }\end{array}$ & Total \\
\hline \multirow[t]{2}{*}{ Educational Services } & $\mathrm{n}=0$ & $\mathrm{n}=4$ & $\mathrm{n}=0$ & $\mathrm{n}=0$ & $\mathrm{n}=4$ \\
\hline & $(0 \%)$ & $(13,3 \%)$ & $(0 \%)$ & $(0 \%)$ & $4,7 \%$ \\
\hline \multirow[t]{2}{*}{ Health Care and Social Assistance } & $\mathrm{n}=2$ & $\mathrm{n}=2$ & $\mathrm{n}=0$ & $\mathrm{n}=0$ & $\mathrm{n}=4$ \\
\hline & $(6,7 \%)$ & $(6,7 \%)$ & $(0 \%)$ & $(0 \%)$ & $4,7 \%$ \\
\hline \multirow{2}{*}{$\begin{array}{l}\text { Agriculture, Forestry, Fishing and Hunt- } \\
\text { ing }\end{array}$} & $\mathrm{n}=1$ & $\mathrm{n}=0$ & $\mathrm{n}=0$ & $\mathrm{n}=2$ & $\mathrm{n}=3$ \\
\hline & $(3,3 \%)$ & $(0 \%)$ & $(0 \%)$ & $(8,7 \%)$ & $3,5 \%$ \\
\hline \multirow[t]{2}{*}{ Finance and Insurance } & $\mathrm{n}=3$ & $\mathrm{n}=0$ & $\mathrm{n}=0$ & $\mathrm{n}=0$ & $\mathrm{n}=3$ \\
\hline & $(10 \%)$ & $(0 \%)$ & $(0 \%)$ & $(0 \%)$ & $3,5 \%$ \\
\hline \multirow[t]{2}{*}{ Communication (massive media) } & $\mathrm{n}=0$ & $\mathrm{n}=1$ & $\mathrm{n}=0$ & $\mathrm{n}=1$ & $\mathrm{n}=2$ \\
\hline & $(0 \%)$ & $(3,3 \%)$ & $(0 \%)$ & $(4,3 \%)$ & $2,3 \%$ \\
\hline Administrative and Support and Waste & $\mathrm{n}=1$ & $\mathrm{n}=1$ & $\mathrm{n}=0$ & $\mathrm{n}=0$ & $\mathrm{n}=2$ \\
\hline Management and Remediation Services & $(3,3 \%)$ & $(3,3 \%)$ & $(0 \%)$ & $(0 \%)$ & $2,3 \%$ \\
\hline \multirow[t]{2}{*}{ Utilities } & $\mathrm{n}=0$ & $\mathrm{n}=1$ & $\mathrm{n}=0$ & $\mathrm{n}=0$ & $\mathrm{n}=1$ \\
\hline & $(0 \%)$ & $(3,3 \%)$ & $(0 \%)$ & $(0 \%)$ & $1,2 \%$ \\
\hline \multirow[t]{2}{*}{ Real Estate Rental and Leasing } & $\mathrm{n}=0$ & $\mathrm{n}=1$ & $\mathrm{n}=0$ & $\mathrm{n}=0$ & $\mathrm{n}=1$ \\
\hline & $(0 \%)$ & $(3,3 \%)$ & $(0 \%)$ & $(0 \%)$ & $1,2 \%$ \\
\hline \multirow{2}{*}{$\begin{array}{l}\text { Management of Companies and Enter- } \\
\text { prises }\end{array}$} & $\mathrm{n}=1$ & $\mathrm{n}=0$ & $\mathrm{n}=0$ & $\mathrm{n}=0$ & $\mathrm{n}=1$ \\
\hline & $(3,3 \%)$ & $(0 \%)$ & $(0 \%)$ & $(0 \%)$ & $1,2 \%$ \\
\hline \multirow[t]{2}{*}{ Arts, Entertainment, and Recreation } & $\mathrm{n}=0$ & $\mathrm{n}=1$ & $\mathrm{n}=0$ & $\mathrm{n}=0$ & $\mathrm{n}=1$ \\
\hline & $(0 \%)$ & $(3,3 \%)$ & $(0 \%)$ & $(0 \%)$ & $1,2 \%$ \\
\hline \multirow[t]{2}{*}{ TOTAL } & $\mathrm{n}=30$ & $\mathrm{n}=30$ & $\mathrm{n}=3$ & $\mathrm{n}=23$ & $\mathrm{n}=86$ \\
\hline & $100 \%$ & $100 \%$ & $100 \%$ & $100 \%$ & $100 \%$ \\
\hline
\end{tabular}

indicate how much they agree or disagree with a series of statements to measure managers' attitudes. A 7-point Likert scale, ranging from "strongly disagree" to "strongly agree," computes their answer. In addition, most managers provided complete responses to perceptual questions (85 out of 86 respondents).

Figure 4 shows managers' attitudes towards internationalization as a proxy by their responses to two general statements. Specifically, managers were asked to indicate to what extent they agree or disagree with two views. First, for "Internationalization is the only way to achieve our growth objectives," we find managers' average agreement with such a statement is higher at higher category levels, suggesting that managers recognize a need to engage internationally to accomplish their growth objectives. There is a statistically significant difference between managers' average responses in domestically focused firms and internationally engaged firms. Second, for "We see no need to internationalize any part of our business," we find managers' average agreement with such a statement is higher at lower category levels, which suggests managers of firms from lower framework category levels do not perceive a need to engage in international business activities.

Figure 5 shows managers' attitudes towards market scope as a proxy by their responses to two general statements. Specifically, managers were asked to indicate to what extent they agree or disagree with two statements. First, for "The market in which we operate is global in nature," we find managers' average agreement with such a statement is higher at higher category levels, which suggests managers are more globally minded at higher category levels. 


\section{Figure 4}

Management Attitudes Towards Internationalization

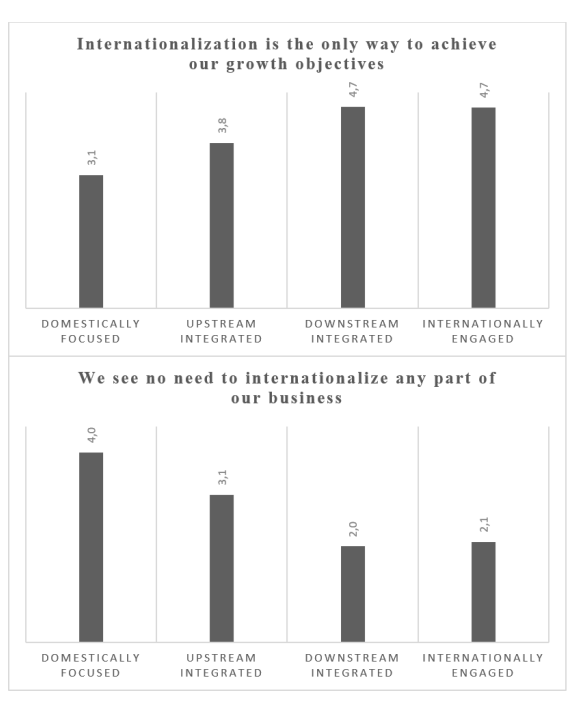

Second, for "We see our future as being primary in the Chilean market," we find higher average managerial agreement with such a statement at lower category levels, suggesting that managers of firms from lower framework category levels do not anticipate engaging in international business activities. Finally, there is a statistically significant difference between the average responses of managers across the four classification categories.

Table 3 shows managers' perceived capabilities associated with internationalization as a proxy by their responses to multiple general statements. The managers' average responses to most comments show the expected direction. For instance, with "We know how to purchase from prospective suppliers in foreign markets," managers of firms in the upstream integrated and internationally engaged categories show a higher average response (5.4 and 5.3; respectively) than managers of firms in the domestically focused (4.0) and the downstream integrated (4.0) categories. Furthermore, there is a statistically significant difference between the average responses of managers in the upstream integrated and internationally engaged categories and the other two categories. Thus, Chilean managers whose firms are engaged in international upstream value chain activities agree more with a statement suggesting they know how to source from foreign suppliers than those who do not do it.

Similarly, for "We know how to market to prospective customers in foreign markets," managers of firms in the downstream integrated and internationally engaged categories show higher average responses (6.3 and 5.2; respectively) than managers of firms in the domestically focused (4.1) and upstream integrated (4.0) categories. There is also a statistically significant difference between average responses from managers in the downstream integrated and internationally engaged categories and the other two categories. Thus, Chilean managers whose firms are involved in international downstream value chain activities agree more with a statement suggesting they know how to market to prospective foreign customers than those who do not do it.

The analysis of perceived capabilities can be 


\section{Figure 5}

Management Attitudes Towards Market Scope



enhanced by modifying or incorporating some questions that may give information about network dynamics of the firms in the four categories and find out whether this parameter has some significant differences among the categories, in order to extent and deepen the study. The methodologies developed by Coviello (2006) and Von Zedtwitz and Gassmann (2002) are interesting inputs for a broader study, considering networking and innovation. This extension can be improved by considering innovation pace, as developed in Franco and Esteves (2020) and Hilmersson and Hilmersson (2021). The analysis used in the latter studies should be modified to state the four categories defined in the internalization framework, incorporating the other dimensions considered in the aforementioned studies.

Table 4 shows managers' perception of firm performance as a proxy by their responses to multiple general statements. Again, there is a high affinity for most statements in general; most average ratings are above 4 points. For instance, when asked "Internationalization has had a positive effect on corporate profitability," managers of firms in the downstream integrated and internationally engaged categories gave the highest average response (5.7); managers of firms in the upstream combined category had a medium average response (5.3), and managers of firms in the domestically focused category showed the lowest average response (4.4). Therefore, managers of firms that are partially engaged in international business activities show statistically significant higher average responses. Similarly, a positive effect of internationalization is observed in value chain improvements, company image, earnings stability, and organization expertise. On the other hand, managers do not perceive clear performance benefits associated with internationalization in sales growth, market share growth, and risk levels.

\subsection{Tree-Decision Model}

The model was run using all the variables, to identify the most relevant parameter to decide which strategy to follow regarding sales and purchases; i.e., whether to remain in the domestic 
Table 3

Perceived Capabilities Associated with Internationalization

\begin{tabular}{|c|c|c|c|c|c|}
\hline & & $\begin{array}{l}\text { Domestically } \\
\text { Focused }\end{array}$ & $\begin{array}{l}\text { Upstream Inte- } \\
\text { grated }\end{array}$ & $\begin{array}{l}\text { Downstream } \\
\text { Integrated }\end{array}$ & $\begin{array}{l}\text { Internation- } \\
\text { ally Engaged }\end{array}$ \\
\hline \multirow[t]{3}{*}{ * } & $\begin{array}{c}\text { Our production/service capacity does } \\
\text { not allow us to serve international } \\
\text { markets. }\end{array}$ & 4.1 & 4.1 & 5.0 & 2.7 \\
\hline & $\begin{array}{l}\text { Daily business operations do not allow } \\
\text { us to think about buying internation- } \\
\text { ally. }\end{array}$ & 4.2 & 3.2 & 3.0 & 2.7 \\
\hline & $\begin{array}{l}\text { The prices at which we source in do- } \\
\text { mestic markets are very competitive. }\end{array}$ & 4.6 & 4.6 & 4.0 & 3.8 \\
\hline * & $\begin{array}{l}\text { We know how to purchase from pro- } \\
\text { spective suppliers in foreign markets. }\end{array}$ & 4.0 & 5.4 & 4.0 & 5.3 \\
\hline * & $\begin{array}{l}\text { Our production/service needs do not } \\
\text { require us to purchase from interna- } \\
\text { tional markets. }\end{array}$ & 4.7 & 2.9 & 5.0 & 2.9 \\
\hline * & $\begin{array}{l}\text { Our product/services prices do not } \\
\text { allow us to compete in international } \\
\text { markets. }\end{array}$ & 3.7 & 3.3 & 3.3 & 2.3 \\
\hline * & $\begin{array}{l}\text { We know how to market to prospec- } \\
\text { tive customers in foreign markets. }\end{array}$ & 4.1 & 4.0 & 6.3 & 5.2 \\
\hline * & $\begin{array}{l}\text { Our financial resources do not allow } \\
\text { us to engage in international opera- } \\
\text { tions. }\end{array}$ & 4.1 & 4.6 & 4.6 & 2.5 \\
\hline * & $\begin{array}{c}\text { Our current product/service offerings } \\
\text { are inadequate to serve international } \\
\text { markets. }\end{array}$ & 3.5 & 4.2 & 3.6 & 2.7 \\
\hline * & $\begin{array}{c}\text { Daily business operations do not allow } \\
\text { us to think about selling internation- } \\
\text { ally. }\end{array}$ & 4.0 & 4.1 & 2.3 & 2.6 \\
\hline
\end{tabular}

Note: ${ }^{\star}$ Indicates statistically significant differences among matrix categories.

market or to participate in the international market. The model has better explanations for internationally engaged companies, whose decision would depend upon the percentage of sales they have in the international market (91\%), and the method used to acquire inputs and services from abroad (8\%). For the domestically focused and upstream integrated, there are some parameters whose answer would be zero, that appear as the most relevant. The downstream integrated firms are too few in the sample to apply the model. Therefore, considering the survey structure, part of the questions that have very distinguished answers for the 4 groups should be used. This kind of analysis should be done in future research. 


\section{Table 4}

Perceived Performance Benefits Associated with Internationalization

\begin{tabular}{|c|c|c|c|c|c|}
\hline & & $\begin{array}{l}\text { Domestically } \\
\text { Focused }\end{array}$ & $\begin{array}{l}\text { Upstream } \\
\text { Integrated }\end{array}$ & $\begin{array}{c}\text { Downstream } \\
\text { Integrated }\end{array}$ & $\begin{array}{l}\text { Internation- } \\
\text { ally Engaged }\end{array}$ \\
\hline & & 4.4 & 4.6 & 5.7 & 4.8 \\
\hline & $\begin{array}{l}\text { IB activities have contributed above } \\
\text { average growth rate in market share. }\end{array}$ & 4.4 & 4.4 & 4.7 & 4.7 \\
\hline & $\begin{array}{l}\text { IB activities have contributed higher } \\
\text { profit margins as a result of selling in- } \\
\text { ternationally. }\end{array}$ & 4.2 & 4.3 & 4.7 & 5.0 \\
\hline & $\begin{array}{l}\text { IB activities have contributed higher } \\
\text { profit margins as a result of sourcing } \\
\text { internationally. }\end{array}$ & 4.3 & 5.1 & 4.0 & 4.8 \\
\hline * & $\begin{array}{l}\text { Internationalization has had a positive } \\
\text { effect on corporate profitability. }\end{array}$ & 4.4 & 5.3 & 5.7 & 5.7 \\
\hline * & $\begin{array}{c}\text { IB activities have contributed higher } \\
\text { operational efficiency levels. }\end{array}$ & 4.3 & 5.1 & 6.3 & 4.7 \\
\hline * & $\begin{array}{c}\text { IB activities have contributed higher } \\
\text { levels of improvements in our value } \\
\text { chain }\end{array}$ & 4.5 & 5.3 & 6.3 & 5.2 \\
\hline & $\begin{array}{l}\text { IB activities have contributed better } \\
\text { overall performance than competitors. }\end{array}$ & 4.5 & 5.1 & 6.0 & 4.9 \\
\hline * & $\begin{array}{l}\text { IB activities have contributed less vola- } \\
\text { tility in earnings. }\end{array}$ & 4.0 & 5.0 & 4.3 & 4.8 \\
\hline & $\begin{array}{l}\text { IB activities have contributed more di- } \\
\text { versified and less risky operations. }\end{array}$ & 4.2 & 4.9 & 5.3 & 5.2 \\
\hline * & $\begin{array}{l}\text { IB activities have contributed positive } \\
\text { effect on the image of our company/ } \\
\text { SBU }\end{array}$ & 4.7 & 5.3 & 6.3 & 6.1 \\
\hline * & $\begin{array}{l}\text { IB activities have contributed positive } \\
\text { effect on the expertise of our compa- } \\
\text { ny/SBU. }\end{array}$ & 4.7 & 5.3 & 6.3 & 6.0 \\
\hline
\end{tabular}

Note: ${ }^{\star}$ Indicates some statistically significant differences among matrix categories.

\subsection{Movement Across Framework Categories}

To understand Chilean firms' movement across framework categories, we asked respondents to indicate the year when the company began operations, the year when it first sold products or services internationally, and the year when it initiated sourced input factors internationally (De la Fuente-Mella et al., 2020a). Managers' responses to those questions allow us to identify firm movements across framework categories.
Figure 6 shows that 28 out of 30 firms classified as domestically focused (category 1) began in this category and remained in it; one company moved into this category from the upstream integrated category. The other came from the downstream integrated class. 22 out of 30 firms classified as upstream integrated (category 2) moved from the domestically focused category, six businesses began and remain in category 2 , and 2 firms moved into the upstream integrated category from the internationally engaged category. 
All companies classified in the downstream integrated category (category 3) began as domestically focused and moved into this category. Finally, 18 out of 23 firms ranked as internationally engaged (category 4) began as domestically focused and driven into this category (these businesses began upstream and downstream value chain activities the same year at some point during their life), one firm moved into the internationally engaged category from the downstream integrated category, two companies moved into the internationally engaged category from the upstream integrated category, and two corporations began and remained in category 4 ; the so-called born global firms (these businesses began upstream and downstream value chain activities the same year in which they were born). These findings suggest a substantial number of Chilean companies move from being domestically focused towards international engagement. A larger number of firms tap international markets through upstream value chain activities rather than downstream activities. Many firms move from category 1 (domestically focused) to category 4 (internationally engaged) directly, bypassing categories 2 and 3 ; these companies began international upstream and downstream value chain activities within the same year. Thus, we find there is a movement towards internationalization as well as the inward direction. In other words, some Chilean firms engage and disengage from international markets across time; managers appear to be responding to changing international market conditions that make international business activities more or less attractive across time.

\section{Conclusions and Comments}

The analysis of the results highlights companies' behavior according to the categories and their emphasis provides some hypothesis support, according to these groups of businesses. The first finding is that the internationalization value chain framework is validated as an instrument to study companies' position depending on their domestic and international exchange. The framework is consistent with the theory regarding the ranking to which an organization belongs. The results prove four hypotheses considered in the literature: company profitability, internationalization through subsidiaries, international perspectives, and

\section{Figure 6}

Firm Movement Across Framework Classification Categories

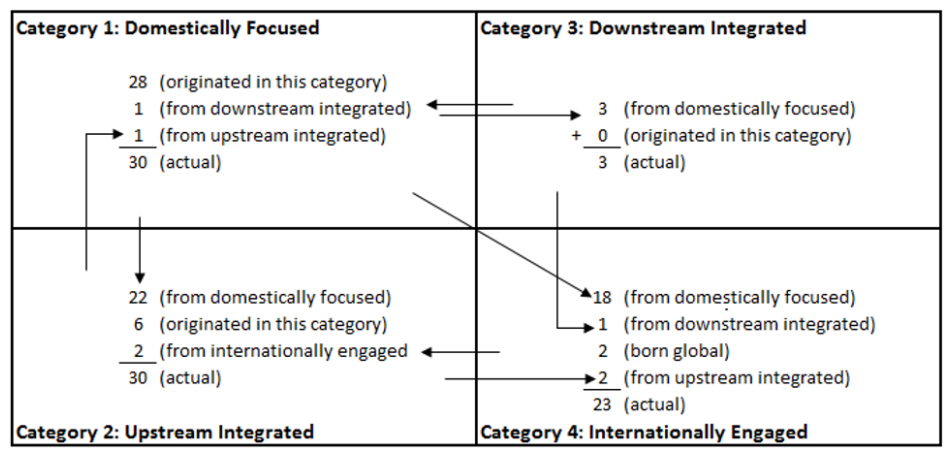


perception about consumer availability in foreign markets. Likewise, the framework can be used to develop business models that include the international panorama, allowing the creation and development of new enterprises, boosting employment and economic activity.

A second conclusion is the relevance of Chilean companies' internationalization. Independent from the business classification, all respondents consider that the international dimension helps business, specifically for corporate image, knowledge transfer, operational efficiency, value chain improvement, and corporate profitability, regardless of their participation in the international market.

Furthermore, there is a contrast between respondents' perception about internationalization levels they perceive in their business and the real degree of international market engagement. This misperception may be affected by the deep degree of opening of the Chilean economy, so that foreign products, relation with expatriates and foreign direct investment may appear closer than they really are. Besides, they may not assign enough time to plan, organize and control activities in foreign markets. The current situation of globalization and deep integration with international markets can also produce the sensation among people that foreign influence is greater than it really is.

The road to internationalization for most companies starts in the domestically focused category. This could be because companies began their operations when Chile was a closed economy, or that most enterprises follow the Upsala model. Some firms also disengaged from international markets, which could be explained by economic crisis, low exchange rate, or deficient foreign market knowledge.

Moreover, there is a majority that approach the foreign market through exports and imports and not foreign direct investment, except the ones in the retail sector. However, ecommerce development may increase cross-border trade over investment in foreign countries, even neighboring countries.

This research shows that there are many dimensions related to business performance in the market, either domestic or international. To pursue further studies, the survey should be applied again to obtain a greater number of companies in the study. Because the survey has many questions, additional support should be given to the respondents, either by telephone communication or video conference. More interaction with business may be recommendable to increase participation and diminish study limitations, in order to design more robust policy recommendations. Another dimension to be studied is improving decision-tree models in order to better identify the array of parameters that determine corporate strategy decisions.

Further research may enlarge the subject of study by deepening analysis of companies' relationship with their suppliers and customers, corporate organizational aspects and their decision about going international or not, or by widening the analysis to other economic parameters relevant to development. Deepening the analysis may be obtained by mixing instruments or ideas developed in different academic studies such as Aslam, Saleem, Khan and Kim (2021) regarding blockchain and supply chain management; using ideas about measuring financial performance as in the model developed by Tomczak (2020); or analyzing tax compliance and formal among categories as Bajrami (2021) suggests.

\section{Acknowledgment}

Funding: Hanns de la Fuente-Mella is supported by Grant Nucleo de Investigacion en Data Analytics / VRIEA / PUCV / 039.432 / 2020

\section{References}

Anand, J., Brenes E. R., Karnani A., \& Rodriguez A. (2006). Strategic responses to economic liberalization in emerging economies: Lessons from experience. Journal of Business Research, 59(3), 365-371. https://doi.org/10.1016/j.jbusres.2005.08.004

Aslam, J., Saleem, A., Khan, N. T., \& Kim, Y. B. (2021). Factors influencing blockchain adoption in supply chain management practices: A study based on the oil industry. Journal of Innovation \& Knowledge, 6(2), 124-134. https://doi.org/10.1016/j. jik.2021.01.002

Aulakh, P. S. (2007). Emerging multinationals from developing economies: motivations, paths, and performances. Journal of International Management, 13(3), 338-355. https://doi.org/10.1016/j.intman.2007.05.001

Autio E., Sapienza H. J., \& Almeida J. G. (2000). Ef- 
fects of age at entry, knowledge intensity, and imitability on international growth. The Academy of Management Journal, 43(5), 909-924. https://doi. org/10.5465/1556419

Bajrami, E. (2021). Recognition of taxes and implementation of tax procedures by SMEs in Albania. Contemporary Economics, 15(2), 224-240. https:// doi.org/10.5709/ce.1897-9254.445

Bianchi, C. (2014). Internationalisation of emerging market firms: An exploratory study of Chilean companies. International Journal of Emerging Markets, 9(1), 54-78. https://doi.org/10.1108/IJoEM-02-2010-0013

Brenes, E. R. (2000). Strategies for globalization Latin American firms. Journal of Management Reviews, 50(1), 3-7.

Bucley, P. J., \& Cason M. C. (1976). The future of multinational enterprise. The Macmillan Press.

Carneiro, J., \& Brenes E.R. (2014). Latin American firms competing in the global economy. Journal of Business Research, 67, 831-836. https://doi. org/10.1016/j.jbusres.2013.07.001

Christensen, C. H., da Rocha A., \& Gertner R. K. (1987). An empirical investigation of the factors influencing exporting success of Brazilian firms. Journal of International Business Studies, 18, 6177. https://doi.org/10.1057/palgrave.jibs.8490412

Coviello, N. E. (2006). The network dynamics of international, new ventures. Journal of International Business Studies, 37(5), 713-731. https://doi. org/10.1057/palgrave.jibs.8400219

Cuervo-Cazurra, A. (2007). Sequence of value-added activities in the multinationalization of developing countries firms. Journal of International Management, 13, 258-277. https://doi.org/10.1016/j. intman.2007.05.009

Cuervo-Cazurra, A. (2008). The multinationalization of developing countries: The case of Multilatinas. Journal of international Management, 14, 138-154.

Curci, R., Mackoy R., \& Yagi N. (2012). The internationalization of businesses in the greater Indianapolis area: Understanding their scope and strategies. Journal of Management Policy and Practice, 13(1), 67-90.

Curci, R., Mackoy R., \& Yagi N. (2013). Stages and paths of firm internationalization: Testing the value chain internationalization framework. Journal of Comparative International Management, 16(1), 3-22.

De la Fuente-Mella, H.; Rojas, J. L. \& Leiva, V. (2020a). Econometric modeling of productivity and technical efficiency in the Chilean manufacturing industry. Computers \& Industrial Engineering, 139(2020), 105793. https://doi.org/10.1016/j. cie.2019.04.006.

De la Fuente-Mella, H.; Vallina, A.M. \& Solis, R. (2020b). Stochastic analysis of the economic growth of OECD countries. Economic ResearchEkonomska Istraživanja, 33(1), 2189-2202. https:// doi.org/10.1080/1331677X.2019.1685397

Dominguez, L. V., \& Sequeira, C. G. (1993). Determinants of LDC exporters' performance: A crossmational study. Journal of International Business Studies, 24(1), 19-40. https://doi.org/10.1057/palgrave.jibs. 8490223

Dunning, J. H. (2008). Trade, location of economic activity and the MNE: A search for an eclectic approach. In B. Ohlin, P. Hesselborn, P. M. Wijkman (Eds.), The international allocation of economic activity. The Macmillan Press Ltd., 395-431. https:// doi.org/10.1007/978-1-349-03196-2_38

Fleury, A. \& Fleury M. T. L. (2011). Brazilian multinationals: Competences for internationalization. Cambrige University Press.

Franco, M., \& Esteves, L. (2020). Inter-clustering as a network of knowledge and learning: Multiple case studies. Journal of Innovation \& Knowledge, 5(1), 39-49. https://doi.org/10.1016/j.jik.2018.11.001

Geldres, V., Etchebarne M.S., \& Bustos L.H. (2011). La distancia psíquica y el desempeño exportador: un reto para la pyme en la era de la globalización [The psychic distance and export performance: A challenge for SMEs in a globalization era]. Estudios Gerenciales, 27(118), 85-96. https://doi. org/10.1016/S0123-5923(11)70147-4

Hilmersson, F. P., \& Hilmersson, M. (2021). Networking to accelerate the pace of SME innovations. Journal of Innovation \& Knowledge, 6(1), 43-49. https://doi.org/10.1016/j.jik.2020.10.001

Ickis, J. (2000). Implementing globalization strategies in Latin America. Journal of Business Research, 50(1), 9-13

Johanson, J., \& Vahlne J. E. (2009). The Uppsala internationalization process model revisited: From liability of foreignness to liability of outsidership. Journal of International Business Studies. 40, 1411-1431. https://doi.org/10.1057/jibs.2009.24

Johanson, J., \& Wiedersheim P. F. (1975). The internationalization of the firm - four Swedish cases. Journal of Management Studies, 12(3), 305-323. https://doi.org/10.1111/j.1467-6486.1975. tb00514.x

Knight, G. A., \& Cavusgil S. T. (1996). The Born Global firm: A challenge to traditional internationaliza- 
tion theory. Advances in International Marketing, 8, 11-26.

Lederman, D., Messina J., Pienknagura S., \& Rigolini J. (2014). Latin American entrepreneurs: Many firms but little innovation. World Bank.

Lou, Y., \& Tung, R. L. (2007). International expansion of emerging market enterprises: A springboard perspective. Journal of International Business Studies, 38, 481-498. https://doi.org/10.1057/palgrave. jibs. 8400275

Madsen, T., \& Servais P. (1997). The internationalization of Born Global: An evolutionary process? International Business Review, 6(6), 581-583. https:// doi.org/10.1016/S0969-5931(97)00032-2

Milesi, D., Moori V., Robert V., \& Yogul G. (2007). Developing competitive advantages: Successful export SMEs in Argentina, Chile and Colombia. Cepal Review, 92, 25-43.

Paz, A. De la Fuente-Mella, H., Singh, A. Conover, R., \& Monteiro, H. (2016). Highway expenditures and associated customer satisfaction: a case study. Mathematical Problems in Engineering, 2016(4630492), 1-9. https://doi. org/10.1155/2016/4630492.

Pérez-Batres, L. A., Pisani, M. J., \& Doh, J. P. (2010. Latin America's contribution to IB scholarship. Academy of International Business Insights, 10, 3-7.

Poblete, C., \& Amorós, J. E. (2013). Determinantes en la Estrategia de Internacionalización para las Pymes: el Caso de Chile [Determinants in the Internationalization Strategy for SMEs: The case of Chile]. Journal of technology management \& innovation, 8(1), 97-106. https://doi.org/10.4067/ S0718-27242013000100010

Santiso, J. (2008). La emergencia de las Multilatinas [The emergence of Multilatinas]. Cepal Review, 95, 7-30.

Schulz, A., Borghoff T., \& Kraus S. (2009). International entrepreneurship: Towards a theory of sme internationalization. Journal of International Business \& Economics, 9(1), 1.

Suhatrini, Hudayati, A., Alsayegh, M. F., Rahman, R. A., \& Kamarulzaman, R. (2020). The corporate culture's moderating effect on the logistics service quality and market flexibility relationship of Indonesian manufacturing companies. Contemporary Economics, 14(4), 501-512. https://doi. org/10.5709/ce.1897-9254.422

Thomas, E., \& Grosse R. E. (2005). Explaining imports and exports: A focus on Non-Maquiladora Mexican firms. Multinational Business Review, 13(3), 2540. https://doi.org/10.1108/1525383X200500013
Tomczak, S. K. (2020). Multi-class Models for assessing the financial condition of manufacturing enterprises. Contemporary Economics, 14(2), 219236. https://doi.org/10.5709/ce.1897-9254.401

Vallina, A. M., De la Fuente-Mella, H., \& Solis, R. (2020). International trade and innovation: Delving in Latin American commerce. Academia ARLA, 33(3), 4535-547, https://doi.org/10.1108/ ARLA-07-2020-0174.

Vernon, R. (1966). International investment and international trade in the product cycle. The Quarterly Journal of Economics, 80(2), 190-207. https://doi. org/10.1016/B978-0-12-444281-8.50024-6

Von Zedtwitz, M., \& Gassmann, O. (2002). Market versus technology drive in $\mathrm{R} \& \mathrm{D}$ internationalization: four different patterns of managing research and development. Research Policy, 31(4), 569-588. https://doi.org/10.1016/S0048-7333(01)00125-1

Westhead, P., Wright, M., \& Ucbasaran, D. (2001). The internationalization of new and small firms: A resource-based view. Journal of Business Venturing, 16(4), 333-358. https://doi.org/10.1016/S08839026(99)00063-4

Zahra, S. A. (2003). International expansion of US manufacturing family businesses: The effect of ownership and involvement. Journal of Business Venturing, 18(4), 495-512. https:/doi. org/10.1016/S0883-9026(03)00057-0

Zucchella, A., Palamara, G., \& Denicolai, S. (2007). The drivers of the early internationalization of the firm. Journal of world business, 42(3), 268-280. https:// doi.org/10.1016/j.jwb.2007.04.008 